\title{
The Implication of the Globalization on the Pancasila-Based Principles of Local Democracy in Indonesia
}

\author{
Seno Wibowo Gumbira, ${ }^{*}$ Jamal Wiwoho** \\ DOI: https://doi.org/10.22304/pjih.v6n2.a8
}

\begin{abstract}
The liberalism principles have influenced the whole life aspects of the nation and the state of Indonesia. On the political aspect, the principles influence the elections in Indonesia from the lowest (village head election) to the highest (presidential election) levels. The liberal principles are not in accordance with the principles of Pancasila as the national philosophy and the source of law (staatsfundamental norm) of Indonesia. The liberal democratic principles cause high cost democracy. They create the conditions of 'free fight' and 'homo homini lupus', as well as many potential corruption practices in villages. In addition, it can lead to the most worrying issue -the damage of values of Pancasila.
\end{abstract}

Submitted: April 5, 2019 | Accepted: October 18, 2019

Keywords: Globalization, Liberal Democratic Principles, Pancasila

\section{Implikasi Pengaruh Globalisasi atas Diseminasi Prinsip-Prinsip Demokrasi Liberalisme terhadap Prinsip-Prinsip Demokrasi Lokal (Desa) berdasarkan Pancasila di Indonesia}

\begin{abstract}
Abstrak
Pengaruh prinsip-prinsip liberalisme telah mempengaruhi seluruh bidang kehidupan bangsa dan negara Indonesia. Pengaruh dalam bidang politik dapat ditemukan pada pemilihan umum yang dilakukan secara voting baik tingkat pemilihan presiden hingga tingkat pemilihan kepala desa di Indonesia, tentunya hal tersebut tidak sesuai dengan Prinsip Pancasila yang merupakan falsafah bangsa dan sumber hukum (staatsfundamentalnorm) di Indonesia. Dampak diseminasi prinsip demokrasi liberalisme melalui voting menyebabkan demokrasi dengan biaya tinggi (high cost) menciptakan kondisi free fight dan homo homini lupus serta banyaknya potensi praktik korupsi di desa dan hal yang paling mengkhawatirkan adalah terjadinya pengikisan nilai-nilai yang terkandung dalam Pancasila.
\end{abstract}

Kata Kunci: Globalisasi, Pancasila, Prinsip Demokrasi Liberal

PADJADJARAN Journal of Law Volume 6 Number 2 Year 2019 [ISSN 2460-1543] [e-ISSN 2442-9325]

Lecturer of the Faculty of Law, Social Studies, and Political Science, Universitas Terbuka, Jalan Cabe Raya, Pondok Cabe-Pamulang, Tangerang Selatan, S.H.,M.H. (Universitas Sebelas Maret), seno@ecampus.ut.ac.id.

** Lecturer of the Faculty of Law, Universitas Sebelas Maret, Jl. Ir Sutami Nomor 36 A, Surakarta, S.H (Universitas Sebelas Maret), M.Hum (Universitas Diponegoro), $\operatorname{Dr}$ (Universitas Diponegoro), jamalwiwoho@staff.hukum.uns.ac.id. 


\section{A. Introduction}

Based on legal perspective, political system legalizes and carries out a system that organizes social relations. It is clear that law is correlated with ideology. In general, ideology refers to a system of political ideas. Both law and politics are interconnected. Ideology enhances entire political spectrum as well as legal system spectrum. Therefore, the discussion of both legal aspect and ideological system such as liberalism, fascism, communism, and so on-must consider law as the expression of legal political ideology. The approved practices and legal activities that are constructed by the people's political beliefs are generated from ideology in simple and controversial method.

In addition, the correlation between ideology and law may affect the adopted economic system. For instance, China adopts a combination of socialism and communism. The state plays a dominant role in carrying out the economy. On the other hand, a state with a liberal ideology like the United States applies a capitalist economic system that gives the market system mechanism for the private sector plays important role in the investment activities. Indonesian financial system is based on Pancasila. Normatively, the Pancasila and the 1945 Constitution of the Republic of Indonesia are the ideal foundation for Indonesian financial system. Indonesia consists of various ethnics and cultures. It is a pluralistic society live on archipelago. It is a challenge for the state to actualize welfare of the citizens and to achieve social justice.

Globalization influences almost all aspects of life such as economics, politics, science, technology, culture, education, and others. ${ }^{2}$ Pye mentions that globalization is a phenomenon of distribution of certain values and cultures throughout the world that may form a newly world culture. ${ }^{3}$ This is related closely to Spybey's idea that globalization is westernization, modernization, or even Americanization ${ }^{4}$. In this sense, globalization is a dynamics where social structures of modernity (capitalism, rationalism, industrialism, bureaucracy, and others) spread throughout the world. This process will likely affect the existence of local wisdom and cultures of a nation. ${ }^{5}$ It can be concluded that globalization includes agenda to spread understanding to influence aspects of economic, political, legal, and others.

The Republic of Indonesia is a state consisting of a variety of tribes and cultures. Certainly, it reflects a pluralistic society with the shape of the territory, the archipelago. It provides challenges for the state to realize the welfare of citizens as the implementation of social justice for all people, especially in the current globalization.

2 Adi Sulistiyanto and Muhamad Rustamaji, Hukum Ekonomi sebagai Panglima, Sidoarjo: Masmedia Buana Pustaka, 2009, p. 25.

3 Lucian W Pye in Sigit Surahman, "Dampak Globalisasi Media Terhadap Seni Dan Budaya Indonesia", Jurnal Komunikasi, Vol. 2, No. 1, 2013, p. 31.

$4 \quad$ T. Spybey, Globalizations and World Society, Cambridge: Polity Press, 1996, p. 157.

5 Herts in T. Spybey, ibid., p. 159. 
Globalization has penetrated almost all areas of people's lives, be it in the fields of economics, politics, science and technology, culture, education, etc. ${ }^{6}$ As stated by Pye, globalization is a symptom of the spread of certain values and cultures throughout the world to become a world culture. ${ }^{7}$ It is closely related to Spybey's idea that globalization is westernization, modernization, or even Americanization. ${ }^{8}$ In this sense, globalization is a dynamic in which the social structures of modernity (capitalism, rationalism, industrialism, bureaucratism, etc.) spread throughout the world. Usually, the process will have the effect of damaging the existence of local wisdom, or the cultures of a nation. ${ }^{9}$ It can be stated that globalization has an agenda to spread a notion to all levels of life to affect the social order of all aspects of economic, political, legal, etc.

The process of the influence of globalization can be happened through cooperation between countries and international organizations/institutions. It is closely related to Spybey's idea that globalization is westernization, modernization, or even Americanization. In this sense, globalization is a dynamic in which the social structures of modernity (capitalism, rationalism, industrialism, bureaucracy, etc.) spread throughout the world. This process will lead to undermining the existence of local wisdom or the cultures of a nation. It can be concluded that globalization spreads notions to all levels of life. It affects the social order. This is based on Giddens' idea that globalization is not only real but also very revolutionary in various dimensions of life.

It is therefore wrong to assume that globalization is only closely related to large systems. Globalization also affects the micro order of human life, for example 'family'. Thus, globalization is a series of complex processes and it takes place in a contradictory form. These contradictory forms can be seen in a number of social phenomena. First, globalization not only builds a new global order, but also a new pressure for the development of local autonomy. Second, it builds a new global culture and stimulates cultural growth or local nationalism (ethno-nationalism). Third, it leads to a multinational economic order and builds regional and local economic zones like in Hong Kong, Italia, and California Silicon Valley. Such changes occur due to various factors, either structural or cultural, especially historical. In the Indonesian economic sphere, the influence of liberalism can be seen when Indonesia signed a letter of intent with the IMF during the economic crisis in the era of 1995. The provisions covered the trade liberalization, the stance of privatization of SOEs, and the stance of freedom of investment in foreign investment.

\footnotetext{
Adi Sulistiyanto and Muhamad Rustamaji, loc.cit.

Lucian W Pye in Sigit Surahman, loc.cit.

T. Spybey, loc. cit.

Herts in Sybey, loc. cit.
} 
The government opens investment for both local and foreign investors to enhance economic capacity of rural areas. The penetration of economic liberalism affects the Pancasila economic system since Indonesia does not recognize liberal economic system. The government gives freedom to foreign parties to explore natural resources of Indonesia. However, the population around these natural resources lives poorly. This occurs due to the processing natural resources and economic system. It happens because the state has not been able to process the available natural resources and to run the Pancasila-based economy.

Indonesia is a pluralistic state that frequently faces conflicts over natural resources involving local communities and companies. For instances, there are tensions between local community and mining corporation in Sape; local community and oil palm companies in Mesuji; and prolonged conflicts involving marginalized local community and Freeport in Papua. These certainly raise an issue. According to Kompas Harian, 300 richest people of Indonesia have worth equal to $60 \%$ of the state budget. The assets of the 40 richest people are equivalent to the wealth of 60 million poorest people; and $80 \%$ of other resources are controlled by foreign parties. ${ }^{10}$

On the other hand, the globalization that contains the spread of liberalism has affected Indonesian politics. The elections in any levels, from Presidential to localscale, are conducted by using voting system. The general election system raises disharmony of executive power from the national to the local-scale. It appears that the power system is based on a system of federalist state power. Furthermore, it is not coherent with the essence of unitary state as contained in the Pancasila as the staatsfundamentalnorm, which is subsequently incoherent with the constitutional provisions of the 1945 Constitution. Article 1 (1) states "The State of Indonesia shall be a unitary state, with the form of a Republic". The Article 1 (2) of the 1945 Constitution (after the amendment) states, "Sovereignty is vested in the people and implemented pursuant to the Constitution". Then, the Law Number 6 of 2014 on Villages, in Article 34, regulates that the election of head of village use the direct election system, which is one of the characteristics of liberal-capitalism democracy. It certainly contradicts to the form of village democracy that has string character with group life characteristics (gemeinschaft) based on intimacy of social identity. The vital social capital in the foundation of community life and politics in the village with the principles of consensus agreement and mutual cooperation in the development of villages throughout the Republic of Indonesia can be said as a dimension that never fade at the grassroots of village community.

Roscoe Pound states that law cannot only be used to perpetuate power but it has a function as a tool of social engineering. It thus raised the question concerning the existence of legal provisions in politics with a voting system as a system of liberal democracy. Does capitalism have implications for the foundation of the

10 Redaksi Kompas, “Kontradiksi dalam Kesejahteraan Umum”, on Kompas, 29 November 2011, p. 6. 
community and politics in the village with the principles of consensus and mutual cooperation in rural development throughout the territory of the Republic of Indonesia and what are the implications?

The establishment of Indonesia is manifested in the politics of communalism and the ideals of the state to bring prosperity. Politically, village, as a political entity that was much older than the state, have a deep historical chronology and communal sociology. This article tries to seek the indirect implications of liberalism within the process of globalization over the principles of local democracy (village) in Indonesia.

\section{B. The Ideology of Pancasila as the Foundation of Indonesian Democracy}

Prior to discussion of the main issue, this paper elaborates the 1945 Constitution of the Republic Indonesia. In the Law Number 12 of 2011 on the Establishment of Legislation, Article 7 (2) states that the legal strength of legislation is in accordance with the hierarchy as referred to in paragraph (1). Therefore, the Indonesian legal system contains the hierarchical (tiered) binding force. However, the Law on the Establishment of Legislation, Article 7 (1), does not mention the position of Pancasila. Therefore, the position of the Pancasila in the Indonesian legal system is above the 1945 Constitution.

Kaelan argues that the Preamble of the 1945 Constitution (Paragraph IV) contains the fundamental basis of the state, such as state's goals, provisions of the state constitution, and the philosophy of Pancasila. Therefore, Paragraph IV has a "causal organic" relationship with the Articles of the 1945 Constitution. Therefore, it is related closely to the contents of the Articles of the 1945 Constitution. ${ }^{11}$ Furthermore, Kaelan states that in the whole legal norms of Indonesian legal system is a hierarchy (tiered). Pancasila is the basis of the philosophy of the Indonesian state and the source of the Indonesian legal order because it is the state's basic norm (staatsfundamentalnorm), followed by the 1945 Constitution, the Decree of MPR, and the laws. ${ }^{12}$

Analyzing the position of Pancasila in the hierarchical structure of the Indonesian legal system, it is related to Kelsen's legal theory of "grundnorm". Kelsen's legal theory covers the position and role of the grundnorm. The grundnorm occupies basic norms as the "initial premise", which is the basis of everything. Kelsen states that grundnorm validity was immediately taken for granted. It is valid because it is presupposed to be valid. ${ }^{13}$

The grundnorm is not classified as a part of positive law that transcends the positive legal system. It is transcendental-logic above the positive law. Therefore, the grundnorm determines the validity of all positive legal arrangements. Hence, the position of the Pancasila in the structure of Indonesian legal system can also be 
referred to as a meta-norm since it is above the positive law of Indonesia. The Pancasila formation is not produced from the legislature. Kelsen also states, "the basic norm is not created by procedure by a law creating organ ... by legal act ... It is presupposed to be valid because without this presupposition no human act could be interpreted as a legal, especially as norm creating, act."14

Thus, the Pancasila can be regarded as the legal basis and source of all laws. All laws and regulations in Indonesia must be based on and not contradict with Pancasila. Further, it shall have implications for the foundation of state philosophy, which is the way of life of Indonesian people. It also has constitutive and regulative functions for the life of the community, the people, and the state. As regard the implementation, actions and decisions of the state practice, both the legal system and the living system of the state must be based on and reflect to the Pancasila. Hence, Pancasila is also a volksgeist of the Indonesian people. Pancasila is a fundamental principle in the formation of the 1945 Constitution.

The Pancasila principles are addressed along with the points according to the Decree of the People Consultative Assembly (MPR) Number I/MPR/2003 as follows.

Table 1. The Principles of Pancasila

\begin{tabular}{|c|c|c|c|c|}
\hline $\begin{array}{l}\text { First Principle } \\
\text { of Pancasila, } \\
\text { Belief In the } \\
\text { One and Only } \\
\text { God }\end{array}$ & $\begin{array}{l}\text { Second Principle } \\
\text { Just and Civilized } \\
\text { Humanity }\end{array}$ & $\begin{array}{l}\text { Third } \\
\text { Principle } \\
\text { The Unity of } \\
\text { Indonesia }\end{array}$ & $\begin{array}{l}\text { Fourth Principle } \\
\text { Democracy } \\
\text { Guided by the } \\
\text { Inner Wisdom in } \\
\text { the Unanimity } \\
\text { arising out of } \\
\text { Deliberations } \\
\text { amongst } \\
\text { Representatives }\end{array}$ & $\begin{array}{l}\text { Fifth Principle } \\
\text { Social Justice } \\
\text { for the Whole } \\
\text { People of } \\
\text { Indonesia }\end{array}$ \\
\hline $\begin{array}{l}\text { The } \\
\text { Indonesian } \\
\text { people } \\
\text { expresses its } \\
\text { belief and } \\
\text { piety towards } \\
\text { the God } \\
\text { Almighty }\end{array}$ & $\begin{array}{l}\text { Everyone } \\
\text { recognizes and } \\
\text { treats human } \\
\text { beings according } \\
\text { to their dignity as } \\
\text { creatures of God } \\
\text { Almighty }\end{array}$ & $\begin{array}{l}\text { Able to place } \\
\text { the unity, } \\
\text { interests and } \\
\text { safety of the } \\
\text { nation and } \\
\text { state as a } \\
\text { common } \\
\text { interest } \\
\text { above } \\
\text { personal and } \\
\text { group } \\
\text { interests }\end{array}$ & $\begin{array}{l}\text { As a citizen, } \\
\text { every Indonesian } \\
\text { has equal } \\
\text { position, rights } \\
\text { and obligations }\end{array}$ & $\begin{array}{l}\text { Developing } \\
\text { noble deeds, } \\
\text { which reflect } \\
\text { the attitude } \\
\text { and } \\
\text { atmosphere } \\
\text { of family and } \\
\text { mutual } \\
\text { cooperation }\end{array}$ \\
\hline $\begin{array}{l}\text { The people of } \\
\text { Indonesian } \\
\text { believe and }\end{array}$ & $\begin{array}{l}\text { Everyone } \\
\text { recognizes } \\
\text { equality of rights }\end{array}$ & $\begin{array}{lr}\text { Able } & \text { and } \\
\text { willing } & \text { to } \\
\text { sacrifice } & \text { for } \\
\end{array}$ & $\begin{array}{l}\text { not forcing own } \\
\text { will to others }\end{array}$ & $\begin{array}{l}\text { Developing a } \\
\text { fair attitude } \\
\text { towards }\end{array}$ \\
\hline
\end{tabular}

14 Ibid. 


\begin{tabular}{|c|c|c|c|c|}
\hline $\begin{array}{l}\text { have piety to } \\
\text { the Almighty } \\
\text { God, } \\
\text { according to } \\
\text { their } \\
\text { respective } \\
\text { religions and } \\
\text { beliefs based } \\
\text { on just and } \\
\text { civilized } \\
\text { humanity }\end{array}$ & $\begin{array}{l}\text { and basic } \\
\text { obligations of } \\
\text { every human } \\
\text { being, without } \\
\text { distinguishing } \\
\text { ethnicity, } \\
\text { ancestry, religion, } \\
\text { belief, gender, } \\
\text { social position, } \\
\text { skin color, etc. }\end{array}$ & $\begin{array}{l}\text { the interest of } \\
\text { the state and } \\
\text { nation if } \\
\text { necessary }\end{array}$ & & others \\
\hline $\begin{array}{l}\text { Everyone } \\
\text { develops a } \\
\text { respectful } \\
\text { attitude to } \\
\text { respect and } \\
\text { to cooperate } \\
\text { among } \\
\text { adherents of } \\
\text { religions and } \\
\text { beliefs }\end{array}$ & $\begin{array}{l}\text { Everyone } \\
\text { develops mutual } \\
\text { love for humans }\end{array}$ & $\begin{array}{l}\text { Developing } \\
\text { love for the } \\
\text { homeland } \\
\text { and the } \\
\text { nation }\end{array}$ & $\begin{array}{l}\text { Prioritizing } \\
\text { deliberation in } \\
\text { making decisions } \\
\text { for common } \\
\text { interests }\end{array}$ & $\begin{array}{l}\text { Maintaining a } \\
\text { balance } \\
\text { between } \\
\text { rights and } \\
\text { obligations }\end{array}$ \\
\hline $\begin{array}{l}\text { Everyone } \\
\text { fosters } \\
\text { harmony of } \\
\text { life among } \\
\text { fellow } \\
\text { adherents of } \\
\text { religions and } \\
\text { beliefs }\end{array}$ & $\begin{array}{l}\text { Everyone } \\
\text { develops an } \\
\text { attitude of } \\
\text { mutual tolerance } \\
\text { and harmony }\end{array}$ & $\begin{array}{l}\text { Developing a } \\
\text { sense of pride } \\
\text { and } \\
\text { nationalism in } \\
\text { Indonesia }\end{array}$ & $\begin{array}{l}\text { Deliberation to } \\
\text { reach consensus } \\
\text { is covered by a } \\
\text { spirit of family }\end{array}$ & $\begin{array}{l}\text { Respecting } \\
\text { the rights of } \\
\text { others }\end{array}$ \\
\hline $\begin{array}{l}\text { Religion and } \\
\text { beliefs are } \\
\text { issues of } \\
\text { personal } \\
\text { relationship } \\
\text { of human and } \\
\text { God Almighty }\end{array}$ & $\begin{array}{l}\text { Everyone } \\
\text { develops a non- } \\
\text { arbitrary attitude } \\
\text { towards others }\end{array}$ & $\begin{array}{l}\text { Maintaining } \\
\text { world order } \\
\text { based on } \\
\text { freedom, } \\
\text { eternal peace, } \\
\text { and social } \\
\text { justice }\end{array}$ & $\begin{array}{l}\text { Respect and } \\
\text { uphold every } \\
\text { decision reached } \\
\text { as a result of } \\
\text { deliberation }\end{array}$ & $\begin{array}{l}\text { Giving help to } \\
\text { others so they } \\
\text { can stand on } \\
\text { their own }\end{array}$ \\
\hline $\begin{array}{l}\text { Everyone } \\
\text { develops } \\
\text { mutual } \\
\text { respect for } \\
\text { freedom of } \\
\text { worship in } \\
\text { accordance } \\
\text { with their } \\
\text { respective } \\
\text { religions and }\end{array}$ & $\begin{array}{l}\text { Everyone } \\
\text { upholds human } \\
\text { values }\end{array}$ & $\begin{array}{l}\text { Developing } \\
\text { Indonesian } \\
\text { unity on the } \\
\text { basis of Unity } \\
\text { in Diversity }\end{array}$ & $\begin{array}{l}\text { In good faith and } \\
\text { a sense of } \\
\text { responsibility to } \\
\text { accept and } \\
\text { implement the } \\
\text { results of the } \\
\text { deliberation } \\
\text { decision }\end{array}$ & $\begin{array}{l}\text { Not using } \\
\text { property } \\
\text { rights for } \\
\text { businesses to } \\
\text { extort others }\end{array}$ \\
\hline
\end{tabular}




\begin{tabular}{|c|c|c|c|c|}
\hline beliefs & & & & \\
\hline $\begin{array}{lr}\text { Everyone } & \\
\text { does } & \text { not } \\
\text { impose } & \text { a } \\
\text { religion or a } \\
\text { belief } \\
\text { others } & \\
\text { to }\end{array}$ & $\begin{array}{l}\text { Everyone carries } \\
\text { out humanitarian } \\
\text { activities }\end{array}$ & $\begin{array}{l}\text { Promote } \\
\text { association } \\
\text { for the sake } \\
\text { of national } \\
\text { unity and } \\
\text { unity }\end{array}$ & $\begin{array}{l}\text { In the } \\
\text { deliberation, } \\
\text { mutual interests } \\
\text { are above the } \\
\text { personal and } \\
\text { group interests }\end{array}$ & $\begin{array}{l}\text { Not using } \\
\text { property } \\
\text { rights for } \\
\text { wasteful } \\
\text { things and } \\
\text { luxurious } \\
\text { lifestyles }\end{array}$ \\
\hline & $\begin{array}{l}\text { Dare to defend } \\
\text { truth and justice }\end{array}$ & & $\begin{array}{l}\text { Deliberation is } \\
\text { carried out with } \\
\text { common sense } \\
\text { and } \\
\text { accordance with } \\
\text { a noble } \\
\text { conscience }\end{array}$ & $\begin{array}{l}\text { not using } \\
\text { property } \\
\text { rights to } \\
\text { conflict with } \\
\text { or harm the } \\
\text { public } \\
\text { interest }\end{array}$ \\
\hline & $\begin{array}{l}\text { The Indonesian } \\
\text { people feels itself } \\
\text { as part of all } \\
\text { humanity }\end{array}$ & & $\begin{array}{l}\text { Decisions taken } \\
\text { must be morally } \\
\text { accountable to } \\
\text { God Almighty, } \\
\text { uphold human } \\
\text { dignity, values of } \\
\text { truth and justice } \\
\text { prioritize unity } \\
\text { and unity for the } \\
\text { common good }\end{array}$ & $\begin{array}{l}\text { like to hard } \\
\text { work }\end{array}$ \\
\hline & $\begin{array}{l}\text { Developing } \\
\text { respect for } \\
\text { respect and } \\
\text { cooperation with } \\
\text { other nations }\end{array}$ & & $\begin{array}{l}\text { Giving trust to } \\
\text { representatives } \\
\text { who are trusted } \\
\text { to carry out } \\
\text { deliberations }\end{array}$ & $\begin{array}{l}\text { Respecting } \\
\text { the work of } \\
\text { others that is } \\
\text { beneficial to } \\
\text { improve and } \\
\text { mutual } \\
\text { prosperity }\end{array}$ \\
\hline & & & & $\begin{array}{l}\text { Doing } \\
\text { activities in } \\
\text { order to } \\
\text { realize } \\
\text { equitable and } \\
\text { social justice } \\
\text { improvement }\end{array}$ \\
\hline
\end{tabular}

The second principle of Pancasila states, just and civilized humanity (kemanusiaan yang adil dan beradab). Point 2 states that it recognizes uniformity, equality, and basic obligations of every human being, without distinguishing ethnicity, ancestry, religion, belief, gender, social position, skin color, etc. Certainly, the fundamental of the second principle and its points is the principle of the Article 
18B (2) of the 1945 Constitution. It states, "The state recognizes and respects customary law units along with their traditional rights as long as they are alive and in accordance with the development of the community and the principle of the Unitary State of the Republic of Indonesia, which is regulated in laws". Thus, Article 18 B (2) of the 1945 Constitution recognizes the existence of the tribes and communities of customary law throughout Indonesia as long as they are alive and in accordance with the development of society and the principle of the Unitary State of the Republic of Indonesia. Thus, the custom community who lives in a village is recognized by the government and regulated by the Law Number 6 of 2014 on Villages (the Village Law). The formation looks like based on the Article $18 \mathrm{~B}$ (2) of the 1945 Constitution in which the provisions constitute the concretization of the second precept contained in the Pancasila as ideology, especially in value of humanity. As the five basic values, which include divinity, humanity, unity, populism, justice is the essence of the Pancasila precepts that are universal and interrelated each other because the basic values contain good and right ideals as well as objectives.

This is due to the consequence that based on the theory of grundnorm, it is clear that the position of Pancasila can be elaborated and proven as a grundnorm. In relation to Kelsen's theory, Pancasila can be considered the basis of all legal sources of legislation at the both central and regional levels. It also regulates system, principles, types, and material of the contents of the legislation. Consequently, laws and regulations may not contradict with the rules. In its culmination, it must not contradict with Pancasila as the basic norm and the 1945 Constitution as the highest law. Therefore, the values of Pancasila must influence every norm. The Pancasila and the 1945 Constitution mandate a value in the establishment of every legislation. However, the question arises whether the whole articles contained in the Village Law purely reflect the values of Pancasila as Ideology. In the second question related to the Pancasila in the constellation of laws in Indonesia, one of its dimensions is the norm of criticism, which is to be a touchstone for the underlying norms. ${ }^{15}$

To address the first question, it is known that the pattern or structure of the interaction of Indonesian people with various cultures, especially in villages, is the form of communal society. Even though Indonesian people are heterogeneous in terms of ethnicity, race, customs, and religion, they still united for common interests, especially in villages. In the provisions of Article 1 (1) of the Village Law, it is explained that villages are customary villages and villages or referred to by other names, hereinafter referred to as villages, are legal community units that have territorial limits to be regulated and administered by the government affairs, interests based on community initiatives, origin rights, and/or traditional rights that are recognized, and respected in the system of government of the Unitary State of

15 Muladi, “Menggali Kembali Pancasila Sebagai Dasar Pengembangan Ilmu Hukum”, Jurnal Hukum Progresif, Vol. 1, No. 1, 2005, p. 198. 
the Republic of Indonesia. Thus, the political policy of the Village Law gives recognition to the political system of villages based on governmental entities managed autonomously in line with the original, potential, and socio-cultural characters of villages in the entire territory of Indonesia. This situation can be a moment of the democracy values that has become the lifeblood of communal life in the countryside (Communitarianism Democracy). ${ }^{16}$

Indonesian people are multicultural and really holding the tradition, especially they who live in the remote area. For example, the instrument is 'village consultation' at the Village Consultative Body (BPD-Badan Perwakilan Desa) as regulated in the Village Law. It consists of the villagers based on regional representation who are elected democratically (deliberation and consensus). The functions are regulated in the Law. Article 54 (1) to (4) essentially addresses village consultation are consultative forums that are followed by village consultative bodies, village governments, and elements of the village community. It is to "discuss" strategic matters in the implementation of Village Government, including village arrangement, planning, collaboration, investment plans, the establishment of village-owned enterprise, addition and release of Village Assets, and extraordinary events. It is carried out at least once a year.

Then, in the explanation of the Village Law for Article 54, the village conference is a meeting forum of all stakeholders of village, including the community, to outline the things that are considered important by the village government and also concerning the needs of the village community. Furthermore, in the explanation, the definition of "community elements" includes traditional leaders, religious leaders, community leaders, educational figures, representatives of farmer groups, anglers' groups, crafters groups, women's groups, and poor groups.

Thus, it is clear that, in the Village Law, village consultation is an important instrument in determining strategic policies ranging from changes of village nomenclature, economy, to matters related to government to achieve welfare improvement in general and to educate all indigenous peoples who collected in the village unit. Deliberation is a decision-making forum that has been known for a long time and has become part of the country's foundation. This can be said to reflect the fourth principle of Pancasila, which mentions that democracy guided by the inner wisdom in the unanimity arising out of deliberations amongst representatives. Thus, the Village Law also adheres to the method of deliberative democracy literally in this term means consultation, considering or in the political popular term referred to as musyawarah. ${ }^{17}$ This deliberative democracy is the opposite of liberal democracy in the form of voting.

Soetardjo Kartohadikoesoemo, Desa, Jakarta: Balai Pustaka, 1983, p. 73.

Habermas in Kaelan, Inkonsistensi dan Inkoherensi Dalam Undang-Undang Dasar Negara Republik Indonesia 1945 Hasil Amandemen (Kajian Filosifis dan Yuridis), Yogyakarta: Paradigma, 2016, p. 175. 


\section{Election of Village Head Based on Voting System is Contrary to the Ideology of Pancasila}

Deliberation, which is a character of rural communities, is especially carried out in the process of determining policy, the selection of a leader, and the actualization of common interests. It is a mechanism that has been tested for decades. To answer the second question, the Article 34 of the Village Law regulates the following:

1. The Village Head is elected directly by the villagers;

2. The election of the Village Head is direct, general, free, confidential, honest, and fair;

3. The election of the Village Head is carried out through the nomination, voting, and stipulation stages;

4. In carrying out the election of the Village Head, as referred to in paragraph (2), the Village Head election committee is formed;

5. The election committee stated in paragraph (4) request a screening of candidates according to the specified conditions, carrying out the voting, assigning elected candidate, and reporting the accomplishment of Village Head elections;

6. Village Head Election Fee is charged to the Regency/City Regional Revenue and Expenditure Budget;

The direct election by voting is an adaptation of liberal democracy. It is, in this case, is not in accordance with the basic values, the instrument, and the practice of Pancasila. Therefore, there is an inconsistency.

As stated earlier, globalization is a dynamic in which the social structures of modernity (capitalism, rationalism, industrialism, bureaucracy, and others) spread throughout the world and usually this process damages the existence of local wisdom. Of course, the voting system, which is considered the modernization of the democratic system, will certainly threatens the existence of the Pancasila democratic system. Given the impact of globalization put forward by Giddens that globalization is not only real but also very revolutionary in various dimensions of life, therefore, it is wrong to assume that globalization is only closely related to large systems. Globalization also influences the micro order of human life, for example 'family'. Thus, globalization is a complex set of processes and everything takes place in a contradictory form. These values of contradiction can be seen in a number of social phenomena. First, globalization does not only build a new global order but also new pressure for the development of local autonomy or local nationalism (ethno-nationalism). Second, it leads to a multinational economic order and builds regional and local economic zones, such as those in the Hong Kong, Italy, and the California Silicon Valley. Such changes occur due to various factors, both structural and cultural, especially the historical value ${ }^{18}$.

18 Anthony Giddens, The Constitution of Society: Teori Strukturasi Untuk Analisis Sosial, Penerjemah Adi Loka Sujono, Yogyakarta: Pedati, 2003, p. 140. 
Based on Pancasila values, especially the fourth principle, populism is led by wisdom in representative deliberations. This implies the meaning of democracy to the people, not to individuals, representative consultation and meaningful wisdom to everything that leads to goodness. It can be concluded that the Pancasila democracy is not only based on competition, but also on a kindness of life together. The system of village head election with a voting system is a system of democracy based on philosophical individualism and liberalism as developed by Locke and Hobbes that the state is a joint will of individuals to form a legal society.

Based on the Article 54, the instruments of democracy are village consultations (musyarawah) as the character of democratic instruments. On the contrary, the Article 34 of Village Law regulates that the village head election must be conducted by voting. It is a characteristic of liberal democracy. The two systems cannot be integrated, of course. The application of village head election by voting will affect the whole democracy and the cost is also expensive. Although in it's a normative provision, the costs of village head election become the responsibility of the Regency/City Regional Revenue and Expenditure Budget. In practice, there is the potential of money politics that may ultimately increase the implementation of corruption practices in the village. This reflected by the following facts.

1. There were two village heads in Bone, South Sulawesi, who were suspected in the Village Fund Budget corruption case worth more than half a billion rupiah. The two village heads were proved to have collaborated in the misappropriation of the village funds. The Village Head admitted that he used 300 million rupiah of ADD money for his campaign during the election. ${ }^{19}$

2. A few days before the Village Head Elections, which were held simultaneously, the Office of the District Attorney General of Sidoarjo claimed to receive ten reports of alleged corruption crime cases. The average incoming report involved village heads who mostly run as candidates on the simultaneous elections in 70 villages in Sidoarjo Regency. ${ }^{20}$

3. Based on the records of Indonesia Corruption Watch (ICW) from 2016 to mid2017, there were 110 corruptions of village budgets that have been processed by law. They allegedly involved 139 perpetrators. The amount of state losses incurred reached at least 30 billion rupiah. ${ }^{21}$

In addition, other effects are certainly at the Village Consultation, which is a deliberative forum followed by the Village Consultative Body, Village Government,

19 Detik News, "2 Kades Ini Ngaku Korupsi Ratusan Juta Rupiah Untuk Kampanye", https://news.detik.com/berita/d-4154194/2-kades-ini-ngaku-korupsi-ratusan-juta-rupiah-untuk-kampanye, accessed on 11 December 2018.

20 Momentum, "Jelang Pilkades Kejaksaan Klaim Terima 10 Laporan Korupsi", https://hukrim.memontum.com/12758-jelang-pilkades-kejaksaan-klaim-terima-10-laporan-korupsi, accessed on 11 December 2018.

21 Nasional Kompas, "Tak Tersentuh KPK Kades Jadi Aktor Korupsi Anggaran Desa Terbanyak", https://nasional.kompas.com/read/2017/08/11/23514291/tak-tersentuh-kpk-kades-jadi-aktor-korupsianggaran-desa-terbanyak, accessed on 11 December 2018. 
and elements of the Village Community to "discuss" strategic matters in the implementation of Village Government. The forum will be difficult to reach consensus and will find deadlock in every discussion concerning the development of the village. Therefore, the Village Consultative Body will remain use the liberal democracy instruments by voting, considering the many factors of interest by the Village Consultative Body, Village Government, and elements of the Village community itself.

The deeper effect of inconsistencies is inability to achieve fair distribution. Due to the large number of factors of interest by the village consultative body, village government, and elements of the village community led to the distribution of social goods for the welfare of the local village community or indigenous peoples, which caused social gap, or inequality. Walzer states that all forms of the justice concept are the result of human construction, which lives in a community with the values it adheres to. The consequence is there will be no single notion of justice that can be applied universally. For Walzer, there are various problems the formulation of justice and there is always a room for cultural and political differences. In other words, the principle of forever-pluralistic justice and various social assets must be shared on a different basis with different procedures and agents. ${ }^{22}$ Therefore, justice is always rooted in our perceptions of place, employment-and-position, honor, various goods-and-needs, and all things that together, but differently, shape the pattern of our lives. Getting rid of all the differences and complexity is an unfair act. Therefore, the liberalism of justice that is considered general or universal is impossible. ${ }^{23}$

Walzer in Suharto tries to map the characteristics of justice ${ }^{24}$ that the concept of character or the characteristics of justice is pluralistic-radical. There is no universal law regarding justice. Justice must be seen as a creation of a political community in a certain period. Its judgment must be based on what is given from within the community itself. It is implausible to say that a hierarchical type of society is unjust because the distribution of social needs does not take place according to the principle of equality.

It can be concluded that justice is not just a question of interpretation and application of distribution criteria but also differences and boundaries between different spaces. For Walzer, it is very fundamental that no social goods may be used in terms of domination. Therefore, Walzer rejects the conception that the concentration of political power, wealth, honor, and especially government, is in the one power or authority. Thus, compared to the discussion of the potential for inequity in the distribution of social goods for the welfare of the community, it is necessary to find fair distribution model. According to experts, there are three

Michael Walzer, Sphere of Justice: A Defense of Pluralism and Equality, New York: Basic Books, 1983, pp. 5-6.

23 Edi Suharto, Negara Kesejahteraan Sosial Indonesia: Antara Hasrat dan Jerat Globalisasi Neoliberal, Bandung: Alfabeta, 2010, p. 43.

24 Ibid., p. 314. 
common criteria to determine the extent to which a distribution process can be considered to produce distributive justice: ${ }^{25}$ equity, equality, and need.

In the element of equity, the reward for someone must be equal to the contribution to the community. Equality means that everyone gets the same share, regardless of the input or contribution. Need is the basic criteria for distribution based on needs. Therefore, people who need more are considered fair to get more shares. Those whose needs less are considered fair to get a small share. Hence, fair allocation of resources or distributive justice is crucial for the stability of shared life in society and the welfare of all citizens. If the issue of distributive justice is not handled properly and the things that should be distributed fairly and equally, it turns out that, it is also very important in the life of the community, thus the violent conflict is usually unavoidable. ${ }^{26}$

The potential of real threat to the survival of the state with Pancasila's philosophy could lead to national disintegration, such as when the communal village community eliminated the Pancasila-based consensus and prioritize the implementation of village government system with liberal democracy. The comparison of Liberal Democracy and Deliberative Democracy, according to Eko can be seen as follows. ${ }^{27}$

Table 2. The Comparison between Liberal Democracy and Deliberative Democracy

\begin{tabular}{|l|l|l|}
\hline Classification & \multicolumn{1}{|c|}{ Liberal Democracy } & \multicolumn{1}{|c|}{ Deliberative Democracy } \\
\hline Source & Western Liberal Tradition & Local Wisdom Tradition \\
\hline Basis & Individualism & $\begin{array}{l}\text { Collective based on family- } \\
\text { values }\end{array}$ \\
\hline Substance & Individual Freedom & $\begin{array}{l}\text { Family Values } \\
\text { Cooperation }\end{array}$ \\
\hline Instrument & $\begin{array}{l}\text { Representative Body, Political } \\
\text { Party, and General Election }\end{array}$ & $\begin{array}{l}\text { Community, Village } \\
\text { Conference Village } \\
\text { Consultation, People Forum } \\
\text { Social Association, etc. }\end{array}$ \\
\hline Method & Contestation-Voting & Deliberation \\
\hline Model & Representative Democracy & Deliberative Democracy \\
\hline
\end{tabular}

Liberal democracy is a democracy based on the zero-sum game. It is not a leading indicator in substantial democracy. It can lead to an oligarchic-elitist government. If this happens in the village community, there can be a potential criminal act of corruption, which lead to social gap or inequalities in which the distributive justice

25 Jimmly Asshhiddiqie, Konstitusi Keadilan Sosial Serial Gagasan Konstitusi Sosial Negara Kesejahteraan Sosial Indonesia, Jakarta: Kompas Media Nusantara, 2018, p. 58.

26 Ibid., p. 60.

27 Sutoro Eko, Regulasi Baru, Desa Baru: Ide, Misi, dan Semangat UU Desa, Jakarta: Kementerian Desa, Pembangunan Daerah Tertinggal, dan Transmigrasi, 2015, p. 57. 
process (equity, equality, and needs) is not implemented and lead to conflict and result in separatist movements that causes the disintegration of the nation.

In the consideration of the Village Law, it is explained that the law was formed based on Article 18B (2) of the 1945 Constitution, which is a concretization of the second principle of Pancasila and its points, especially the second point.

However, the substance does not reflect the Pancasila values as the ideology of the people and the state. As stated by Kaelan, democracy should lead people to move towards a more prosperous standard of living. On the contrary, high-cost democracy, where funds are supposed to improve the welfare and living standards of the people, is seized for democratic parties. The results only fulfill the ambitions frequently leads to horizontal conflicts. Hundreds of trillions allocated for euphoria, while people are still struggling with life. In reality, the democratic process only leads political elites to fulfill their power ambitions because the process of highcost democracy results many corrupt officials and political figures, due to the highcost politic. The democratic system today has been based on the principle of free fight and homo homini lupus. Democracy is only for the rich with public funds. Marginalized people who have the right of public funds and elements of the "Unity Republic" do not have the sovereignty because of this condition. ${ }^{28}$

As explained above, the philosophy of the state is closely related to political ideology and law and its economic system. In the context of Indonesia, with Pancasila philosophy, there is a correlation between Pancasila and the 1945 Constitution and social justice. In the constitution, the word 'justice' which is then followed by the word 'social' (keadilan social) stated in paragraph IV of the Preamble of the 1945 Constitution, is not a coincidence of prevalence. It is an actualization of norms that regulates social relations between people in a social space. This is a manifestation of the equality principle in common life naturally, which in everyday life is a form of willingness that useful. Social justice is formulated as the fifth principle in Pancasila but its meaning becomes clearer if we read it directly from the formulation of Paragraph IV of the Preamble of the 1945 Constitution. In Paragraph IV, the first, second, third and fourth precept are formulated statically as objects basic state. On the contrary, social justice is formulated with active sentences. The Paragraph IV reads "...constitution of the Republic of Indonesia which shall be built into a sovereign state based on a belief in the One and Only God, just and civilized humanity, the unity of Indonesia, and democratic life led by wisdom of thoughts in deliberation amongst representatives of the people, and achieving social justice for all the people of Indonesia".

In this case, Kaelan argues that the Paragraph IV contains the fundamentals of the state, namely goals, provisions of the state constitution, and state philosophy of Pancasila. Therefore, Paragraph IV has a "causal organic" relationship with the Articles of the 1945 Constitution. It is closely related to the contents of the Articles

28 Kaelan, Liberalisasi Ideologi Negara Pancasila, Yogyakarta: Paradigma, 2015, p. 25. 
of the 1945 Constitution. ${ }^{29}$ Furthermore Kaelan states, "in the system of legislation in Indonesia, the whole system of legal norms of the Republic of Indonesia is a hierarchical (tiered) system. Pancasila is the basis of the state philosophy in the Indonesian legal order. It is a legal source because it is the basic state norm (staatsfundamentalnorm), followed by verfasungnorm (1945 Constitution), grundgesetznorm (the MPR Decree), and gesetznorm (Law). ${ }^{30}$

Meanwhile, Latif asserted, the only principle of Pancasila formulated in the Preamble of the 1945 Constitution is a statement about one of the state goals in the series of words to realize a social justice for all Indonesian people. A construction of social justice is a moral crystallization. ${ }^{31}$ Pancasila shall be a solution to emphasize some of the vital problems of modern Indonesia. Modern principles such as democracy and human rights ideology have become political starting points in post-reform Indonesia. It points out questions regarding social justice and decision-making processes in Indonesian society. Further, the questions are related to the substance and understanding of humans.

Pancasila, based on the ontological side, includes the precepts of Pancasila. It is not independent principles but has an ontological basis. The ontological basis of Pancasila is essentially human being who have the absolute essence of monopluralism. Therefore, this essence is also referred to as the anthropological basis. The main supporting subject of the principle of Pancasila is human, ${ }^{32}$ while humans as the main supporters of the Pancasila precepts have absolute ontological matters, which consists of the composition of nature, body and soul, body, and spirit. The nature of human beings is as individual beings and social beings as well as personal beings and creatures of God Almighty. Therefore, in the first hierarchy, the first precept underlies the rest of Pancasila precepts. ${ }^{33}$ The conformity relationship between the state and the basic principles of Pancasila is a causal relationship: the state as a supporter of relations, while God, human, and people are just as the basis of relations.

Therefore, to overcome the influence of liberalization of the Pancasila ideology found in indigenous local communities, a strategy to strengthen ideology is necessary. It refers to community-based empowerment, because it is the most strategic effort to build awareness of Pancasila values and prevent national destruction. To achieve this, one of the efforts is to re-establish the upgrading of guidance, appreciation, and practice of Pancasila to all components of the nation starting from the younger generation to create the future with people who formally understand Pancasila and live and practice it. The position and

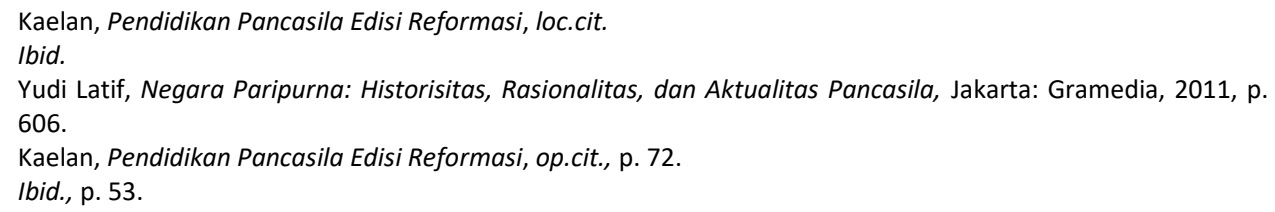


relationship of ideology with law is reciprocity. Law is not only an ideology supported by institutionalized social forces.

It also institutionalizes social forces that is articulated in and reinforced by ideology. In other words, the ideology determines legal products and the legal products strengthens the prevailing ideology. ${ }^{34}$

\section{Conclusion}

Based on the discussion, it can be concluded that there is an inconsistency in the relationship between the Village Law and the 1945 Constitution, which is a concretization of the Pancasila. The Village Law is the liberal democracy and the attachment of indigenous people to their customs. The inconsistency of the Village Law with the 1945 Constitution and Pancasila is correlated to the influence of liberalism, such as the election of village head by voting. This may erode the Pancasila values. One of them is the consensus of village. Due to the high cost of village head election, it can potentially lead to corruption and is impossible to reach agreement on consensus in planning the development and improvement of the welfare of village or indigenous people, as well as unequal distribution in terms of improving the welfare of village indigenous people.

\section{References}

\section{Books}

Adi Sulistiyanto and Muhamad Rustamaji, Hukum Ekonomi Sebagai Panglima, Masmedia Buana Pustaka, Sidoarjo, 2009.

Edi Suharto, Negara Kesejahteraan Sosial Indonesia: Antara Hasrat dan Jerat Globalisasi Neoliberal, Alfabeta, Bandung, 2010.

Giddens, Anthony, The Constitution of Society: Teori Strukturasi Untuk Analisis Sosial, Penerjemah Adi Loka Sujono, Pedati, Yogyakarta, 2003.

Jimmly Asshhiddiqie, Konstitusi Keadilan Sosial Serial Gagasan Konstitusi Sosial Negara Kesejahteraan Sosial Indonesia, Kompas Media Nusantara, Jakarta, 2018.

Kaelan, Inkonsistensi dan Inkoherensi Dalam Undang-Undang Dasar Negara Republik Indonesia 1945 Hasil Amandemen (Kajian Filosifis dan Yuridis), Paradigma, Yogayakarta, 2016.

, Liberalisasi Ideologi Negara Pancasila, Paradigma, Yogyakarta, 2015.

, Pendidikan Pancasila Edisi Reformasi, Paradigma, Yogyakarta, 2016.

Kelsen, Hans, General Theory of Law and State, Russel \& Russel, New York, 1961.

Petrus C. K. L. Bello, Ideologi Hukum: Refleksi Filsafat atas Ideologi di Balik Hukum, Insan Merdeka, Bogor, 2013.

Soetardjo Kartohadikoesoemo, Desa, Balai Pustaka, Jakarta, 1983.

\footnotetext{
34 Petrus C. K. L. Bello, Ideologi Hukum Refleksi Filsafat atas Ideologi di Balik Hukum, Bogor: Insan Merdeka,
} 2013, p. 34. 
Sutoro Eko, Regulasi Baru, Desa Baru: Ide, Misi, dan Semangat UU Desa, Kementerian Desa Pembangunan Daerah Tertinggal, dan Transmigrasi, Jakarta, 2015.

Spybey, T., Globalizations and World Society, Polity Press, Cambridge, 1996.

Walzer, Michael, Sphere of Justice: A Defense of Pluralism and Equality, Basic Books, New York, 1983.

Yudi Latif, Negara Paripurna: Historisitas, Rasionalitas, dan Aktualitas Pancasila, Gramedia, Jakarta, 2011.

\section{Others Document}

Detik News, "2 Kades Ini Ngaku Korupsi Ratusan Juta Rupiah Untuk Kampanye", https://news.detik.com/berita/d-4154194/2-kades-ini-ngaku-korupsi-ratusanjuta-rupiah-untuk-kampanye, accessed on 11 December 2018.

Lucian W Pye in Sigit Surahman, "Dampak Globalisasi Media Terhadap Seni Dan Budaya Indonesia", Jurnal Komunikasi, Vol. 2, No. 1, 2013.

Momentum, "Jelang Pilkades Kejaksaan Klaim Terima 10 Laporan Korupsi", https://hukrim.memontum.com/12758-jelang-pilkades-kejaksaan-klaimterima-10-laporan-korupsi, accessed on 11 December 2018.

Muladi, "Menggali Kembali Pancasila Sebagai Dasar Pengembangan Ilmu Hukum", Jurnal Hukum Progresif Faculty of Law University of Diponegoro Semarang, 2005.

Nasional Kompas, "Tak Tersentuh KPK Kades Jadi Aktor Korupsi Anggaran Desa Terbanyak", https://nasional.kompas.com/read/2017/08/11/23514291/taktersentuh-kpk-kades-jadi-aktor-korupsi-anggaran-desa-terbanyak, accessed on11 December 2018.

Redaksi Kompas, "Kontradiksi dalam Kesejahteraan Umum", on Kompas, 29 November 2011.

\section{Legal Documents}

1945 Constitution of the Republic of Indonesia [Undang-Undang Dasar Negara Republik Indonesia Tahun 1945]

Law Number 5 of 2014 on Village [Undang-Undang Nomor 5 Tahun 2014 tentang Desa] 